\title{
Fra valgstedet til indkøbscenteret: Danskernes stigende brug af brevstemmer
}

Yosef Bhatti, seniorforsker ved KORA, Det Nationale Institut for Kommuners og Regioners Analyse og Forskning

Jens Olav Dahlgaard, ph.d.-studerende ved Institut for Statskundskab på Københavns Universitet

Jonas Hedegaard Hansen, ph.d.-studerende Institut for Statskundskab på Københavns Universitet

Kasper Møller Hansen, Professor ved Institut for Statskundskab på Københavns Universitet Mariann Malchau Olsen, kandidatstuderende ved Institut for Statskundskab på Københavns Universitet

\section{Indledning}

Det bliver stadig mere populært blandt danskerne at brevstemme. Artiklen redegør for ændringer i valgloven og undersøger den empiriske udvikling i anvendelsen af brevstemmer samt hvilke grupper, der i særlig grad benytter stemmeformen.

65,8 procent af borgerne stemte til Kommunalvalget ${ }^{5}$ i 2009. Det var den laveste kommunale valgdeltagelse siden 1974, og for andet valg i træk var valgdeltagelsen under 70 procent. Kommuner, regioner, Folketinget samt en række organisationer udtrykte bekymring for lokaldemokratiets sundhedstilstand og tog en række initiativer $\mathrm{i}$ håb om at få vendt udviklingen. Udover de mange mobiliseringskampagner (se Bhatti et al. 2014a for mere om disse), blev der også sat fokus på institutionelle rammer omkring valghandlingen. Et af de tiltag, der især blev brugt, var at gøre det lettere at stemme inden selve valgdagen. Konkret foretog man ændringer i valgloven, som formelt slækkede på kravene til, hvad der kræves for at måtte brevstemme, ligesom man lettede de formelle krav til rammerne omkring brevstemmeafgivningen (Valgloven, 2015). Kommunerne opstillede ved kommunalvalget i 2013 brevstemmesteder på togstationer, i storcentre og på ungdomsuddannelser,

\footnotetext{
${ }^{5}$ Valgdeltagelsen til Regionalvalg er stort set identisk med den kommunale valgdeltagelse. Af praktiske hensyn skriver vi blot "kommunalvalg" i denne artikel.
} 
så folk på den måde kunne afgive deres stemme i forbindelse med deres dagligdagsaktiviteter. Hvis vælgerne ikke vil komme til valget, må vi bringe valget til dem, syntes devisen at være.

$\mathrm{Vi}$ ved nu, at brevstemmeprocenten - andelen af de samlede afgivne stemmer, som er afgivet som brevstemme - steg fra 3,4 procent i 2009 til 5,3 procent i 2013 (Bhatti et al., 2014c; Bhatti et al., 2014a). De mange tiltag omkring brevstemmer aktualiserer emnet, og der er meget, der tyder på, at den øgede brug af brevstemmer ved 2013-valget ikke var en enlig svale, men en del af en større tendens til at brevstemme. Imidlertid ved vi forskningsmæssigt ganske lidt om udviklingen i Danmark, ligesom der heller ikke er skrevet meget om, hvem der egentlig brevstemmer. Det retter vi op på med denne artikel.

Konkret bidrager artiklen for det første med at beskrive nogle af de tiltag, der er taget i den seneste tid for at øge anvendelsen af brevstemmer samt at give et deskriptiv overblik over den empiriske udvikling i anvendelsen af brevstemmer i Danmark. For det andet bidrager vi med en analyse af brevstemmer på kommuneniveau og analyserer den kommunale variation ved kommunalvalget $\mathrm{i}$ 2013. Det tredje bidrag er på individniveau at analysere, hvilke karakteristika der kendetegner brevstemmerne, hvilket os bekendt ikke tidligere er gjort. Det er muligt at gøre i denne artikel, fordi vi anvender et datasæt med faktisk valgdeltagelse og stemmeform koblet med registerdata fra Danmarks Statistik for mere end 2 millioner danske vælgere i 2013. I forlængelse af denne deskriptive afdækning analyserer vi afslutningsvis, hvilke karakteristika, der kan forklare anvendelsen af brevstemmer, når man tager højde for en række andre variable. Ved at kende til disse forhold kan vi komme et skridt nærmere en forståelse af, hvorfor folk brevstemmer. Da der findes meget lidt forskningsviden om brevstemmer i Danmark, er artiklens formål primært af deskriptiv karakter, om end vi i enkelte delanalyser ser på multivariate sammenhænge.

Øget viden om brugen af brevstemmer er vigtig i forskningsmæssig sammenhæng, fordi det omhandler selve valghandlingens natur og har en lang række demokratiske implikationer. Det påvirker fx, om valget er en begivenhed, der foregår på ét tidspunkt eller i praksis er noget, der bliver spredt ud over flere uger. Desuden er det væsentligt for en række aktører, hvad end det drejer sig om administrationen af valghandlingen eller om fremtidige politiske kampagner. Således kan en stigning i brevstemmeafgivning påvirke planlægningen af valgets afholdelse $\mathrm{i}$ betydelig grad. Ligeledes er strategier for brevstemmetiltag ofte motiveret af, at det potentielt kan mobilisere sofavælgerne. En øget viden om brevstemmer frembragt i en dansk sammenhæng kan således have direkte policykonsekvenser. Endeligt - og såfremt trenden i brevstemmeafgivning fortsætter - kan det have konsekvenser for de politiske kampagner, idet de muligvis skal starte og toppe tidligere end på 
valgdagen for at nå at påvirke de vælgere, de ønsker at nå. Vi diskuterer disse perspektiver yderligere til sidst i artiklen.

\section{Brevstemmer og lovændringer for at øge brugen af brevstemmer}

Inden vi analyserer udviklingen i brugen af brevstemmer over tid, giver vi en kort introduktion til, hvad brevstemmer er samt nylige ændringer i opfattelsen af brevstemmer. En brevstemme er i en dansk sammenhæng en stemme per brev, der indsendes forud for valgdagen (pt. senest to hverdage før valgdagen). En brevstemme kan omgøres indtil tidsfristen for brevstemmeafgivning.

Traditionelt har brevstemmeafgivning været for dem, der var forhindret i at møde op på valgdagen. Det kunne eksempelvis være på grund af dårligt helbred eller rejseaktiviteter. På denne måde var brevstemmen med til at sikre, at alle kunne komme til at afgive deres stemme. Det svarer til det, der på engelsk kaldes "absentee voting" - nemlig at de, som er fraværende på valgdagen, også skal have mulighed for at stemme. Brevstemmen var dog en mulighed, som man ifølge lovgivningen primært kunne benytte sig af, hvis man var "forhindret på valgdagen"6. Officielt var det at brevstemme altså en begrænset mulighed for de, som havde brug for den, om end der i de seneste mange år i praksis ikke har været ført krav om dokumentation for, at man var forhindret.

De seneste år har de lovgivningsmæssige rammer omkring brevstemmer undergået en række formelle ændringer for at gøre brugen af brevstemmer mere fleksibel. Med en lovændring, som trådte i kraft d. 1. januar 2013, blev det formelle krav om at være forhindret ændret, og det var nu tilladt for "enhver valger" at brevstemme (Valgloven, 2015: §53) ${ }^{7}$. I samme forbindelse ændrede man kravene til, hvor brevstemmer skulle afgives. Hvor man førhen skulle afgive sin brevstemme "på folkeregistre", kan man nu afgive sin brevstemme på "de steder i kommunerne, hvor enhver vaelger kan brevstemme” (Valgloven, 2015: §53). Det åbnede op for, at flere danskere kunne få muligheden for at stemme inden valgdagen - fordi der nu hverken var krav til dem eller de steder, hvor de kunne få muligheden for at brevstemme. På denne måde lægger brevstemmelovgivningen i sin nye udformning mere op til det, der på engelsk kaldes 'early voting' - eller det svenske 'förtidsröstning'.

\footnotetext{
${ }^{6}$ Af samme årsag var (og er det stadig) muligt at brevstemme ved indlæggelse/ophold på en række institutioner såsom sygehuse, plejehjem, daghjem og ældreboliger, ligesom det var (og stadig er) muligt at brevstemme i fængsler, i hjemmet hvis man er syg eller har manglende førlighed samt på afsidesliggende øer.

${ }^{7}$ Teksten i Valgloven $\$ 53$ ændrede sig konkret fra "Enhver veelger, der er forhindret $i$ at møde frem til afstemningen på valgdagen, kan brevstemme på ethvert folkeregister her i landet" til "Enhver vaelger kan brevstemme i enhver kommune her i landet". I onlineversionen af Valgloven - som fremgår af litteraturlisten - kan man både læse den nuværende lovgivning samt finde tidligere versioner og ændringer.
} 
Den direkte konsekvens af sådanne lovændringer er nok ret begrænset. Således skal vi ikke gøre os illusioner om, at borgerne selv går ind og læser lovændringerne. Hvis vi skal se en øget brevstemmeafgivning, kræver det nok, at borgerne i praksis oplever, at det er blevet lettere at brevstemme. Her spiller den anden store ændring en betydelig rolle. Således giver den nye lov kommunerne tilladelse til at lave brevstemmesteder væk fra folkeregistrene, og bag lovændringen ligger også et ønske fra mange kommuner om at placere brevstemmestederne der, hvor borgerne opholder sig. Det har kommunerne i høj grad gjort brug af. Udover traditionelle brevstemmesteder som borgerservice og biblioteker satte mange kommuner i forbindelse med kommunalvalget i 2013 brevstemmesteder op på utraditionelle steder som i storcentre og på stationer, ligesom en lang række uddannelsessteder fik besøg af et såkaldt mobilt brevstemmested (Bhatti et al. 2013). Ved at rykke brevstemmestederne tættere på borgernes hverdag, håbede man, at muligheden i højere grad ville blive brugt af vælgere, som ikke ville have stemt på valgdagen. På den måde kan man således argumentere for at have øget både den reelle og oplevede tilgængelighed af brevstemmesteder (Dahlberg, Oscarsson \& Öhrvall, 2007: 31).

\section{Hvorfor så stort fokus på brevstemmer?}

Man kan naturligvis spørge sig selv, hvorfor offentlige myndigheder gør så meget for at lette muligheden for at brevstemme som beskrevet ovenfor. Ideen har et solidt fundament med rødder tilbage til den klassiske rationelle vælgeradfærdsteori, ifølge hvilken man vil forvente, at den øgede og lettere adgang til at brevstemme vil få flere til at stemme (Downs, 1957; Riker \& Ordeshook, 1968). I det perspektiv forventes vælgerens individuelle beslutning om at stemme at blive truffet på baggrund af en overvejelse om omkostninger ved at stemme sammenholdt med, hvad hun får ud af det. Hvis den forventede belønning for at stemme overstiger omkostningerne, vil vælgeren stemme. Sænker man omkostningerne ved at stemme, er der flere, som det kan betale sig for.

For at komme et spadestik dybere, er det i denne sammenhæng brugbart at sondre mellem to typer af omkostninger. For det første er der en række praktiske omkostninger ved at stemme: Man skal hen til sit valgsted, stå i kø, sætte sit kryds og hjem igen (Gronke et al., 2008; Brady \& McNulty, 2011), og man skal gøre det på en bestemt dag, som ikke nødvendigvis passer en. For det andet er der informationsomkostninger: Man skal sætte sig ind i valgets dagsordener og de muligheder, der tilbydes på stemmesedlen (Wolfinger \& Rosenstone, 1980; Lassen, 2005).

Letter man adgang til brevstemmer er det primært de praktiske omkostninger, som vil blive nedbragt for vælgerne. Således skal man ikke tage et nyt sted hen for at afgive sin stemme, men man 
kan i stedet stemme, imens man alligevel venter på toget eller køber ind (Bhatti et al., 2013). Omvendt sker der næppe noget ved informationsomkostningerne som følge af den lettere adgang til at brevstemme. Det kræver fortsat den samme tid at sætte sig ind i sagerne. Der kan argumenteres for, at denne proces er langt mere omkostningsfuld i tid og kognitivt ressourceforbrug end selve stemmeafgivningen (Aldrich, 1993: 248; Ladner \& Pianzola, 2010: 212). Hvis den lettere adgang til at brevstemme skal have en mobiliseringseffekt forstået således, at det er nye vælgere og ikke bare valgstedsvælgere, der bruger muligheden (Gronke et al., 2008; Ladner \& Pianzola, 2010), skal det således være sket som følge af, at de praktiske omkostninger ved at tage til valgstedet førhen var for store for dem (Neeley \& Richardson, 2001).

Overordnet set bør brevstemmemuligheden altså øge valgdeltagelsen ved at sænke omkostningerne ved at stemme, om end det kan diskuteres, hvor vægtige omkostningerne reelt er. Derudover kan den øgede udbredelse af alternative brevstemmesteder medføre en øget opmærksomhed omkring valget. Det kan ske i borgernes hverdag, hvor man i forbindelse med almindelige gøremål kommer til at 'gå ind i' et brevstemmested og derved bliver tvunget til at forholde sig til valget. Derudover kan det ske ved, at medierne bringer historier om de alternative brevstemmesteder, idet de i sig selv er en nyhed. Begge disse muligheder kan tænkes at medvirke til en øget valgdeltagelse.

Man kan dog med udgangspunkt i litteraturen også nævne et potentielt negativt element ved brevstemmer i forhold til valgdeltagelsen. Den individuelle valgdeltagelsesbeslutning udgøres af mere end de blotte omkostninger og potentielle fordele ved at stemme. I denne sammenhæng er det særligt relevant at fremhæve følelsen af at udføre sin borgerpligt ved at afgive sin stemme. Her har flere studier peget på det sociale element ved at afgive sin stemme og på den måde signalere sin udførelse af borgerpligten (fx Blais, Young \& Lapp, 2000; Elklit \& Togeby, 2009). Ved at en stor gruppe af borgere (herunder medlemmer fra ens egen husstand) på samme dag går til stemmeurnerne, opstår der en form for socialt pres, som kan virke mobiliserende på borgere, som potentielt ville vælge sofaen. Ved en stigende overgang til brevstemmer kan man forestille sig, at det sociale pres for at deltage falder (Bhatti et al., 2013), samt at valghandlingen mister noget af sin ceremonielle karakter.

Samlet set har det øgede fokus på brevstemmer altså god grobund i valgdeltagelsesforskningen og især teorien om de potentielt lavere omkostninger ved at stemme. De fleste studier af brevstemmer viser da også små positive eller ingen effekter (Franklin, 2004; Franklin, 1999; Blais, Dobrzynska \& Loewen, 2007). Samtidig skal det påpeges, at brevstemmer næppe er et vidundermiddel, der løser alle valgdeltagelsesproblemer, og at nogle af dem, der brevstemmer, sandsynligvis 
ville have stemt alligevel. Ligeledes kan der være potentielle ulemper i forhold til at mindske det sociale pres til at stemme. Endelig skal det også nævnes at kommunernes udgifter pr. stemmer er væsentligt højere for en brevstemme end en fremmødestemme (Bhatti et al. 2013).

\section{Brevstemmer i historisk og skandinavisk perspektiv}

Vi har i de foregående afsnit set, at der lovgivningsmæssigt har været en udvikling mod at lægge større vægt på brevstemmer - måske ud fra en betragtning om, at det kan øge deltagelsen generelt men har der også over tid været en øget brug af mulighederne? Imens der findes en række udgivelser med fokus på danskernes valgdeltagelse generelt (fx Elklit et al., 2005; Bhatti \& Hansen, 2010; Bhatti et al., 2014c; Bhatti et al., 2014b), findes der så vidt vi ved ingen tidligere samlede videnskabelige kortlægninger af brevstemmere i Danmark. ${ }^{8}$ Figur 1 viser udviklingen i brevstemmeprocenten over tid fordelt på tre hovedtyper af valg. Brevstemmeprocenten er procentandelen af brevstemmer set i forhold til det samlede antal afgivne stemmer ( $\mathrm{fx}$ Danmarks Statistik, 2015: 6).

Som det fremgår af figur 1, er andelen, der brevstemmer til alle typer af valg steget stødt siden 1970. KV2013 er ingen undtagelse. Brevstemmeprocenten på 5,3 var den højeste ved et kommunalvalg i den undersøgte periode. Selv om en række af de seneste valg (fx FV2015) er over trendlinjen, er stigningen på ingen måder begrænset til tiden efter de føromtalte lovændringer.

Brevstemmeprocenten er højest til folketingsvalg. Det er vigtigt at understrege, at det ikke mekanisk skyldes, at valgdeltagelsen til folketingsvalg generelt er højere, idet brevstemmeprocenten er udregnet relativt til de afgivne stemmer. På trods af den markante udvikling med mere end en fordobling i brugen af brevstemmer, står det også klart, at langt størstedelen af vælgerne stadig afgiver deres stemme på valgdagen på et valgsted. I yderligere analyser (ikke vist) finder vi en svag til moderat tendens til, at valg med højere valgdeltagelse også har højere brevstemmeprocent, hvilket kan skyldes, at vælgerne vil gøre særligt meget for at stemme i disse valg. ${ }^{9}$

\footnotetext{
${ }^{8}$ Se dog Bhatti et al., 2013 som i en formidlende artikel opgør udviklingen i brevstemmeprocenten over tid.

${ }^{9}$ I en regression med brevstemmeprocenten som afhængig variabel og stemmeprocenten som uafhængig variabel med kontrol for valgtype og år (kontinuer) samt interaktionen mellem de to (hvilket tillader valgspecifikke udviklingstrends), er koefficienten for stemmeprocenten $0,07(\mathrm{p}=0,059)$. Det svarer til, at en forøgelse af stemmeprocenten på 1 procentpoint øger brevstemmeprocenten med 0,07 procentpoint.
} 
Figur 1: Brevstemmeprocent over tid

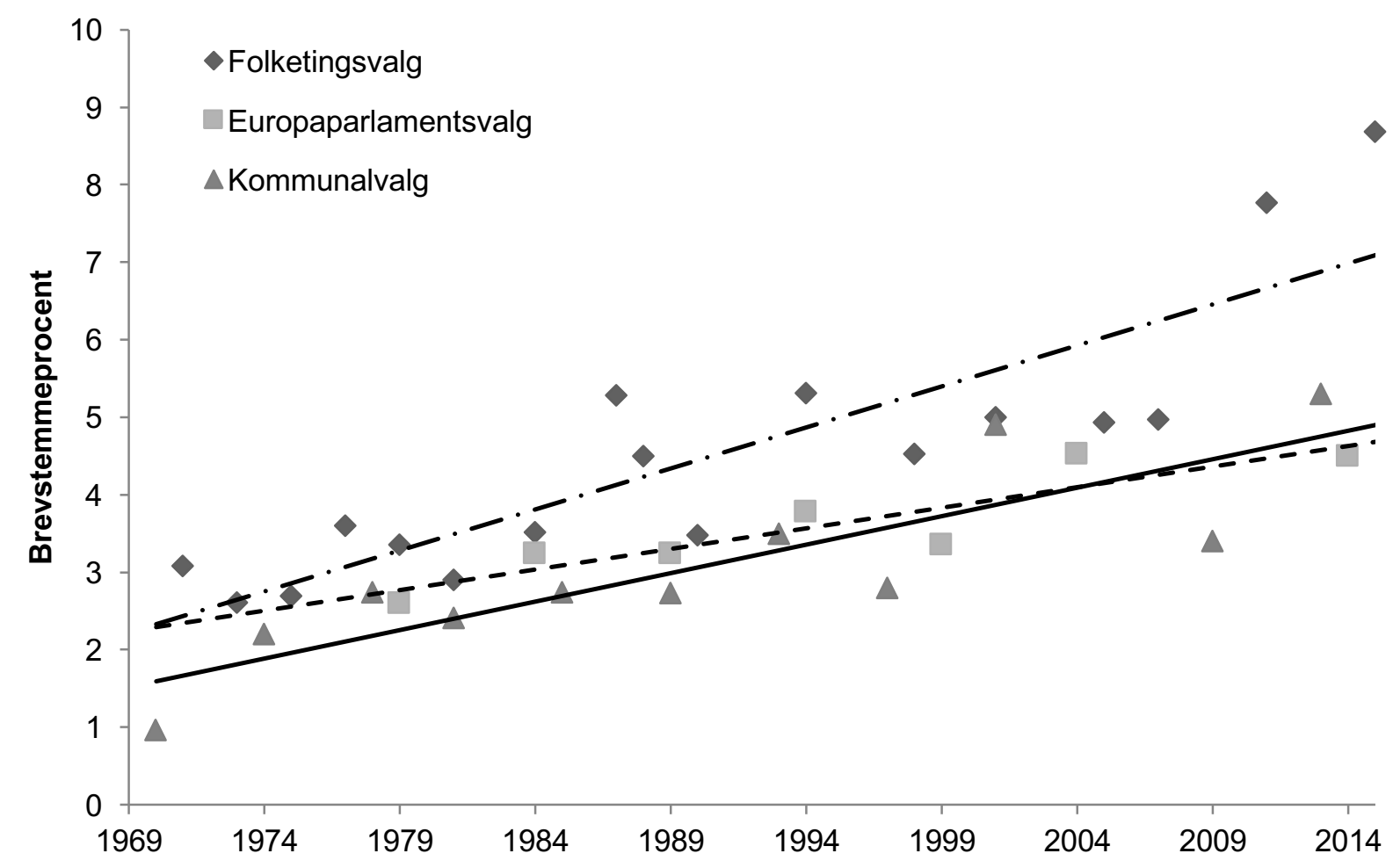

Figur 1 baserer sig på Bhatti et al. 2013, men er opdateret med nye valg. Fuldt optrukket linje er kommunalvalg, stiplet linje (- - - -) er Europaparlamentsvalg og den øverste linje (一•-) er Folketingsvalg).

Sammenligner vi med vores nabolande, ligger Danmarks brevstemmeandel lavt trods stigningen over tid. Eksempelvis har Sverige over de seneste 30 år opbygget en helt anderledes tradition for at brevstemme. Således er det langt mere udbredt at stemme forud for valg i Sverige - og handlingen omtales da heller ikke som "at brevstemme". I stedet bruges ordet "förtidsröstning", der netop understreger, at der blot er tale om, at man afgiver sin stemme før valget (Bhatti et al. 2013). Siden midten af 1980'erne har brevstemmeprocenten til de svenske Riksdagsvalg med en enkelt undtagelse været over 30 procent (Oscarsson \& Holmberg, 2013: 19). ${ }^{10}$ Til sammenligning er den højeste brevstemmeprocent til et valg i Danmark siden 1970 på 8,7 (FV2015), og 4,5 procent brevstemte ved EP2014, mens 5,3 procent brevstemte ved KV2013. Svenskerne har altså i en helt anden grad end danskerne taget brevstemmetraditionen til sig.

\footnotetext{
${ }^{10}$ I Sverige afholdes valg til Riksdagen, regioner og kommuner samtidigt. Opgørelser af brevstemmer er opgjort på Riksdagsvalg, men det bemærkes, at valgdeltagelsen til Riksdagsvalg var ca. tre procentpoint højere den regionale og kommunale valgdeltagelse i 2014.
} 
Også i Norge ser man en langt større anvendelse af brevstemmer end i Danmark. I Norge hedder det "forhåndsstemt", hvilket 30,2 procent af vælgerne (dvs. 30,2 procent af de afgivne stemmer) gjorde ved Stortingsvalget i 2013 (Statistics Norway, 2013). Ved lokalvalget i 2015 stemte 24,3 procent af vælgerne på forhånd (Statistics Norway, 2015). I Finland er niveauet endnu højere end det norske. Således stemte 61,1 procent af vælgerne på forhånd ved det finske parlamentsvalg i 2015, og 42,4 procent af vælgerne brevstemte ved kommunalvalget i 2012 (Ministry of Justice Finland, 2015; Ministry of Justice Finland, 2012). Til sammenligning havde vi ved KV2013 trods et rekordvalg på den front som tidligere omtalt blot en brevstemmeprocent på 5,3.

Vender man til sidst blikket mod Island, hvis brevstemmeregler i høj grad minder om Danmarks, finder man også en højere brug af brevstemmer end herhjemme (Bhatti et al. 2013). Eksempelvis var der 9,9 procent af vælgerne, der brevstemte ved de lokale valg i 2010 (Statistics Iceland, 2015a). Samtidig har der været en betydelig stigning i andelen af brevstemmer ved nationale valg de seneste ti år: Fra 9,7 procent i 2003 til 16,6 procent af vælgerne i 2013 (Statistics Iceland, 2015b). Samlet set har vi altså set en kraftig stigning i brugen af brevstemmer herhjemme både til kommunalvalg og andre typer af valg. Samtidig ligger vi betydeligt under de øvrige nordiske lande.

\section{Brevstemmer på kommuneniveau}

Ovenfor har vi behandlet hele landet under et. Imidlertid er det interessant, om der brevstemmes lige meget $\mathrm{i}$ alle kommuner, eller er kommunale forskelle. I figur 2 vises brevstemmeprocenten for kommunalvalget i 2013 opdelt på de enkelte kommuner (Danmarks Statistik, 2014) ${ }^{11}$ afbilledet sammen med den samlede valgdeltagelse for den pågældende kommune. Der fremgår også en lineær regressionslinje for alle kommuner, samt en linje, hvor ø-kommunerne (dvs. Læsø, Fanø, Ærø og Samsø) ikke inddrages for at se, om der er nogen deskriptiv sammenhæng mellem de to faktorer.

Det mest bemærkelsesværdige i figur 2 er den enorme variation mellem kommunerne. I 2013 var den laveste brevstemmeprocent 2,6 procent i Vejen, mens den højeste fandtes i Gentofte med 11,2 procent. Det er også tydeligt fra figur 2, at det ikke synes at være den overordnede valgdeltagelse, der i hvert fald bivariat forklarer de forskellige brevstemmeprocenter (koefficienten er dog positiv i mange multivariate specifikationer). Modelleres sammenhængen uden de fire ø-kommuner, bliver sammenhængen faktisk svagt negativ (billedet for 2009-valget er stort set identisk med figur 2 og kan ses i appendiks figur A.1).

\footnotetext{
${ }^{11}$ Til sammenligning har vi inkluderet en tilsvarende figur for kommunalvalget $2009 \mathrm{i}$ appendix, tabel a.1. For 2013 mangler der brevstemmeprocenter to kommuner (Lejre og Skive).
} 
Figur 2: Brevstemmeprocent og valgdeltagelse på kommuneniveau i 2013

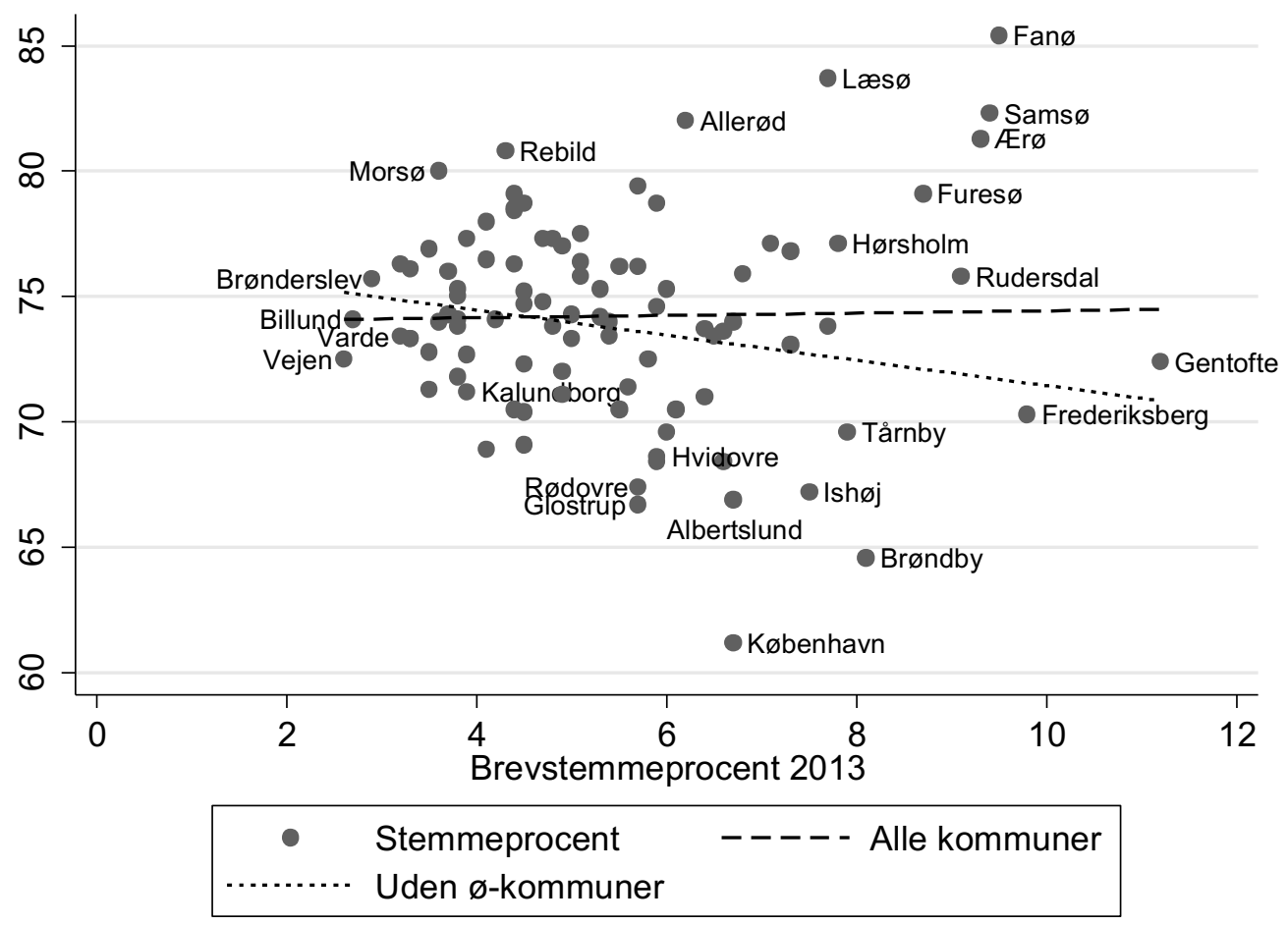

Men hvad kan så forklare variationen mellem kommunerne i figur 2? Uden at det skal blive en udtømmende forklaring, er det bemærkelsesværdigt, at ø-kommunerne ligger højt på brevstemmeprocenten. At ø-kommunerne har en høj brevstemmeprocent kan muligvis forklares ved, at man som vælger har arbejde på fastlandet og derfor har vanskeligere ved at nå hen til valgstedet på valgdagen. Derudover ligger en række relativt velstående kommuner med mange højtuddannede også på en høj brevstemmeprocent. Det kan eksempelvis skyldes borgere, som rejser meget og derfor ikke er hjemme på valgdagen. Samtidig er disse kommuner ofte sammensat af typiske højdeltagelsesborgere (for eksempel højtuddannede, højindkomst, etniske danskere). Man kan på den måde tænke sig, at flere borgere i de velstående kommuner, der er forhindret på valgdagen, får prioriteret at afgive sin stemme på forhånd, imens borgere i mindre velstående kommuner måske blot undlader at stemme. Der synes også at være regionale forskelle. Eksempelvis var den gennemsnitlige brevstemmeprocent i 2013 næsten syv blandt kommunerne i Hovedstadsregionen, hvilket er 1,5 procentpoint højere end Region Sjælland og mere end to procentpoint højere end alle andre regioner. Det skal understreges, at en del af disse regionale forskelle er en konsekvens af regionernes sociodemografiske sammensætning (herunder velstandsniveau og uddannelsesniveau), om end der stadig er statistisk signifikante regionale forskelle, når man kontrollerer for disse faktorer. 


\section{Hvad karakteriserer brevstemmere?}

Vi har nu set, at der er betydelige variationer på kommunalt niveau, og at især vælgerne i Økommuner, kommuner i hovedstadsområdet samt i relativt velstående kommuner brevstemmer oftere end vælgerne i andre kommuner. I dette afsnit går vi helt ned på individniveau og undersøger, hvilke karakteristika, der kendetegner brevstemmerne ved kommunalvalget i 2013. Vi ser således på, om der på tværs af alder, køn, uddannelse og oprindelse er forskel på brevstemmeprocenten. Det sker med udgangspunkt i data indsamlet for samtlige danske vælgere ved kommunalvalget i 2013, hvor alle 98 kommuner deltog i en kortlægning af valgdeltagelsen. For samtlige danske vælgere er det opgjort, om vedkommende stemte eller blev hjemme på valgdagen. I kortlægningen havde 35 kommuner fuldt digitaliserede valglister, og yderligere 25 kommuner havde digitale valglister på nogle af deres valgsteder. For vælgere, der stemte på disse valgsteder, er det muligt at se, om der er tale om en brevstemme eller en fremmødestemme på valgdagen. Vi ser altså nedenfor på de vælgere, som til kommunalvalget i 2013 stemte på et valgsted med digitale valglister (se Bhatti et al., 2014c for mere information om data).

Inden vi begynder på individanalyserne, er det relevant kort at diskutere generaliserbarheden af analyserne, idet vi som nævnt kun har adgang til information om brevstemmer for de vælgere, der stemte på et valgsted med digitale valglister. Konkret har vi adgang til brevstemmeinformation om 2.141.159 stemmeberettigede (49,1 procent af alle stemmeberettigede) og 1.699.143 vælgere på disse valgsteder, hvoraf 100.894 brevstemte. Valgdeltagelsen for den undersøgte gruppe er på 75,1 procent, hvilket er en anelse højere end de 71,9 procent for hele befolkningen. Brevstemmeprocenten på 5,9 er ikke væsentlig forskellig fra brevstemmeprocenten for alle vælgere på 5,3. Væsentligt for generaliserbarheden er, at borgerne ikke kan selektere sig ind i de to grupper. Det minimerer en stor del af de bekymringer, man eventuelt kunne have i forhold til sammensætningen af de to grupper. Derudover ville problemer med at slutte fra de undersøgte borgere til resten af landet kræve, at borgerne tilknyttet de forskellige valgsteder er relativt forskellige fra hinanden, hvilket der ikke er tegn på er tilfældet. Samlet set vurderer vi af ovenstående årsager, at resultaterne nedenfor vil være ganske retvisende for alle landets valgsteder og kommuner. 
Figur 3: Brevstemmeprocent fordelt på alder og køn

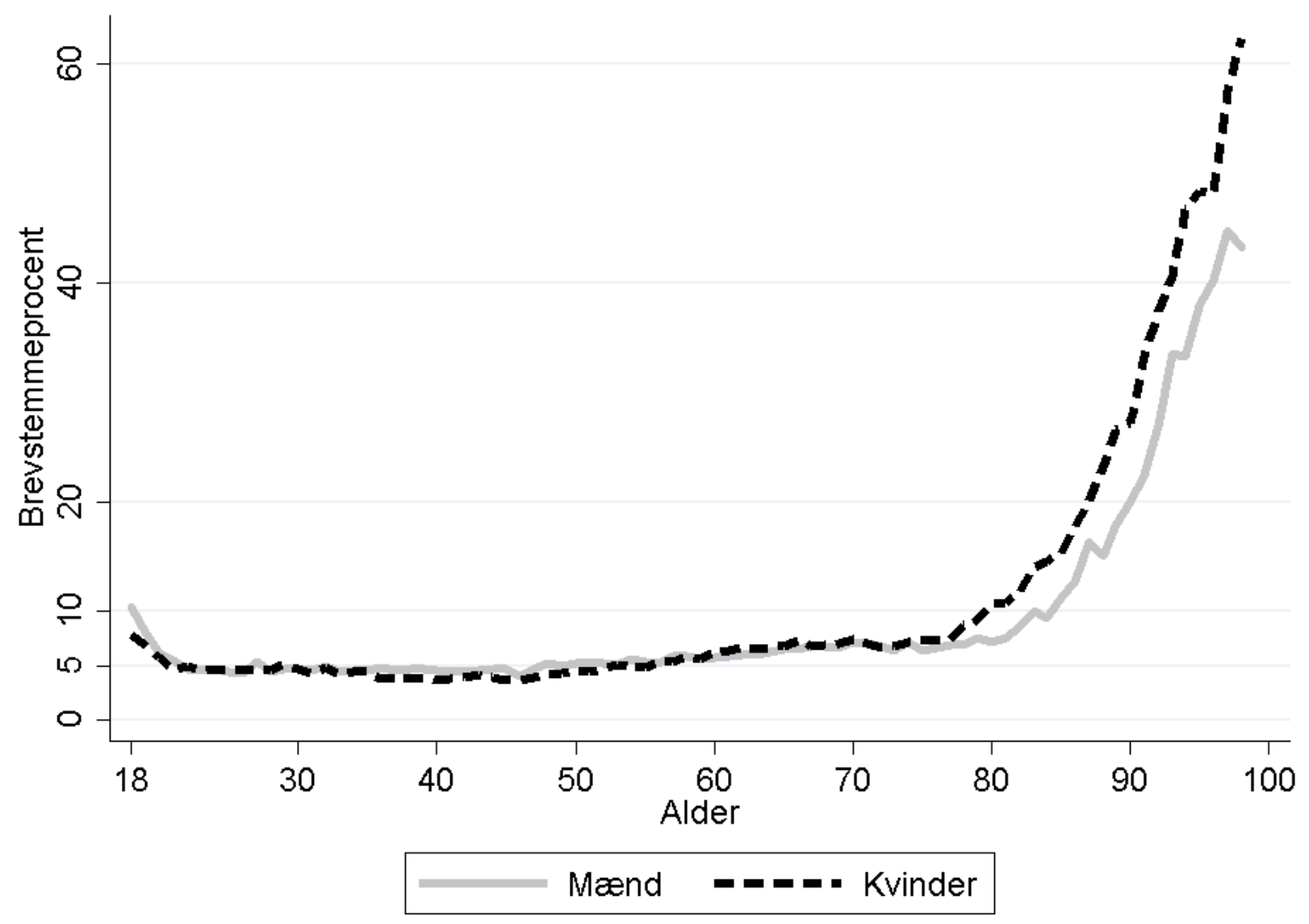

Figur 3 viser, at det i særlig grad er de ældre, som benytter muligheden for at brevstemme. Det er forventeligt, da det både er muligt at brevstemme hjemmefra, hvis der ansøges herom, eller hvis man er indlagt på et hospital eller på plejehjem. Det ses også af figuren, at mænd og kvinder i vid udstrækning brevstemte lige meget ved kommunalvalget i 2013. For de 18 til 75-årige var der således ingen forskel mellem mænd og kvinders tilbøjelighed til at brevstemme. For de 75 til 100-årige ligger kvinderne dog systematisk højere end mændene. En mulig forklaring kan være, at to tredjedele af beboerne på plejehjem er kvinder (jf. Kommission om livskvalitet og selvbestemmelse i plejebolig og plejehjem, 2012: 17), mens kun knap 60 procent af befolkningen over 75 er kvinder. Beboerne på plejehjem har ofte mulighed for at afgive deres brevstemme på plejehjemmet, og hvis kvinderne er overrepræsenteret her, kan det være med til at drive forskellen.

Samtidig viser figur 3, at også de helt unge brevstemmer mere end gennemsnittet. Tager man alle de ekstra brevstemmesteder på uddannelsesinstitutioner ved KV2013 i betragtning, virker det ikke overraskende. I mange kommuner var det muligt at brevstemme på ungdomsuddannelsesinstitutioner i frokostpausen eller i forbindelse med debatarrangementer. For at se nær- 
mere på betydningen af den faktor har vi i supplerende analyser undersøgt, om folk, der er i gang med en uddannelse i højere grad anvender brevstemmemuligheden (se appendiks figur A.2), og denne supplerende analyse viser, at de yngste førstegangsvælgere, der er i gang med en uddannelse, faktisk var en del flittigere brugere af brevstemmer end unge, der ikke var i gang med en uddannelse. En oplagt implikation af det er, at de mange kommuner, der oprettede brevstemmesteder på ungdomsuddannelserne (jf. Bhatti et al., 2014a: 59) i nogen grad lykkedes med at få folk til at anvende dem. Omvendt er førstegangsvælgerne under uddannelse på 20-21 år ikke mere tilbøjelige til at brevstemme. Det giver også mening, idet de fleste af disse ikke går på en ungdomsuddannelse med deraf følgende adgang til et brevstemmested.

Figur 4: Brevstemmeprocent fordelt på alder og oprindelse

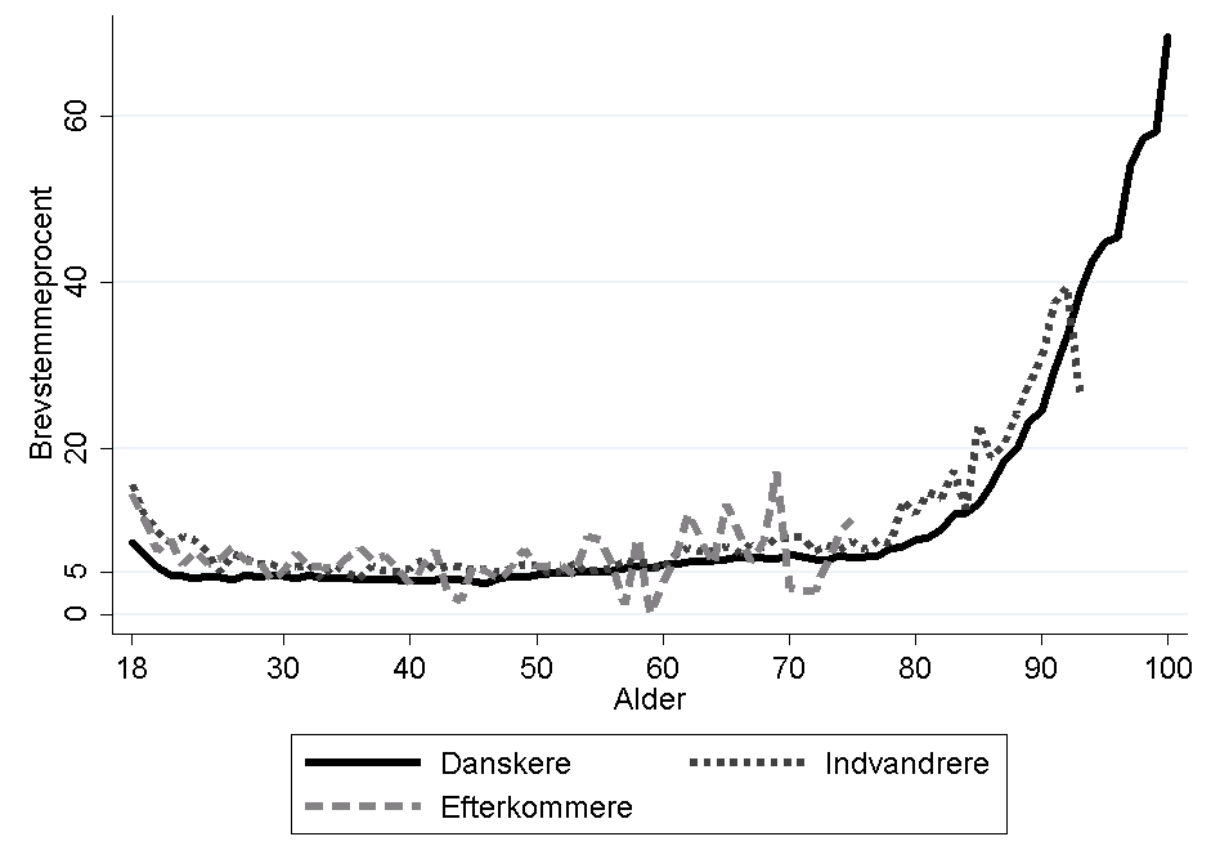

Figur 4 viser, at etniske danskere brevstemmer mindre end efterkommere og indvandrere, især i de ældste og yngste generationer. Præcis hvad det skyldes, kan være vanskeligt at afgøre. Én mulighed er, at nydanskere delvist er orienterede mod deres hjemlande og derfor rejser mere, hvorfor de oftere er forhindrede i at stemme på valgdagen. En anden mulighed er, at selve valghandlingen er forbundet med nogle ritualer og traditioner, som ikke sådan bare lader sig bryde, og som vi redegjorde for tidligere har en del lande markant højere brevstemmeprocenter end Danmark. Hvis man har en vane med at brevstemme, er der gode chancer for, at man bliver ved med det, selvom traditionen $\mathrm{i}$ 
ens nye land er noget andet. For at undersøge denne forklaring nærmere, ser vi i tabel 1 nærmere på niveauet af brevstemmer fordelt på forskellige nordiske oprindelseslande.

Tabel 1. Brevstemmer opdelt på nordiske oprindelseslande

\begin{tabular}{llllll}
\hline $\begin{array}{l}\text { Oprindel- } \\
\text { sesland }\end{array}$ & $\begin{array}{l}\text { Brevstemme- } \\
\text { pct. v. KV13 }\end{array}$ & $\begin{array}{l}\text { Valgdelta- } \\
\text { gelse v. } \\
\text { KV13 }\end{array}$ & $\begin{array}{l}\text { Vælgere v. } \\
\text { KV13 }\end{array}$ & $\begin{array}{l}\text { Brevstemmepro- } \\
\text { cent i oprindelses- } \\
\text { land }\end{array}$ & $\begin{array}{l}\text { Valgdeltagelse i } \\
\text { oprindelsesland }\end{array}$ \\
\hline Danmark & 5,8 & 75,1 & 1.589 .935 & - & - \\
Finland & 8,1 & 54,6 & 1.191 & 42,4 & 58,3 \\
Island & 5,2 & 39,9 & 1.610 & 9,9 & 73,5 \\
Norge & 7,4 & 48 & 4.523 & 40,5 & 60 \\
Sverige & 7,3 & 56,9 & 5.129 & 49,5 & 58,8 \\
USA & 7,9 & 53,1 & 1.581 & 43,5 & 57,5 \\
\hline
\end{tabular}

Note: Valgdeltagelsen er for de vælgere, der er tilknyttet et digitalt valgsted, idet det er for den samme gruppe af vælgere, at brevstemmeprocenten er udregnet på baggrund af. Brevstemmeprocent i oprindelsesland er fra seneste lokale valg i det givne land. Islands tal er fra lokalvalgene i 2010. Sveriges tal er for Riksdagsvalget 2014, som afholdes samtidig med kommunalvalgene og har en anelse højere valgdeltagelse. USA er fra præsidentvalget i 2012.

Det fremgår af tabel 1, at der er relativt mange med oprindelse fra de andre nordiske lande, der brevstemmer set i forhold til etniske danskere (kolonne 1). Det sker samtidig med, at deres valgdeltagelse er betydelig lavere end borgerne med dansk oprindelse (kolonne 2). For at undersøge nærmere, om det skyldes rejser til hjemlandet, der gør, at man er forhindret i at møde op på valgdagen, har vi inkluderet USA i oversigten. I USA anvendes brevstemmer på samme niveau som i Finland, Norge og Sverige (U.S. Election Assistance Commission, 2013). Til gengæld er det markant mere omkostningsfuldt og tidskrævende at rejse til USA, hvilket minimerer sandsynligheden for hyppige besøg. Hvis vælgere med amerikansk oprindelse i samme grad anvender brevstemmer som vælgerne fra de nordiske lande, kan det ses som en løs indikation på, at der ligger mere end praktiske forhold bag adfærden. Det skal i den forbindelse nævnes, at der også kan være andre ting, der varierer mellem USA og de øvrige landes brug af brevstemmer, så tolkningen skal tages med forbehold. Som det fremgår af tabel 1, er de herboende amerikanere markant flittigere brevstemmere end etniske danskere. Deres stemmemønster følger således nogenlunde vælgerne fra de nordiske landes.

Den anden mulige forklaring er som nævnt, at en del af borgerne tager deres vaner omkring måden at stemme på med sig. Denne forklaring bestyrkes af, at islændinge har den laveste brevstemmeprocent af nydanskerne fra de nordiske lande. Som tidligere nævnt kan valghandlingen ses 
som et ritual, hvor man gentager den adfærd, man gjorde ved det seneste valg. Er der tradition for at brevstemme i ens oprindelsesland, vil nogen i så fald have en tendens til fortsat at brevstemme, selvom de går til valg i et land uden en brevstemmetradition. Det er dog vigtigt at understrege, at det ikke er en deterministisk sammenhæng. Som det fremgår af tabel 1 (kolonne 1 og 4) er brevstemmeprocenten for alle grupperne betydeligt lavere end niveauet i oprindelseslandet. Det kunne tyde på, at der finder en læring og tilpasning sted forstået på den måde, at mange vælger at følge den fremgangsmåde omkring valghandlingen, som deres omgivelser gør.

\section{Multivariat analyse af sandsynligheden for at brevstemme}

I den sidste del af analysen undersøger vi, hvilke individkarakteristika som kan være med til at forudsige sandsynligheden for at brevstemme. Det gør vi ved først at lave en multivariat logistisk regressionsanalyse og herefter udregne forudsagte sandsynligheder for at brevstemme, når en række andre variable (køn, alder, uddannelse, oprindelse og indkomst) holdes på deres gennemsnit. Figur 5 viser de forudsagte sandsynligheder for fire variable, hvor de øvrige variable holdes på deres gennemsnit.

Figur 5. Forudsagte sandsynligheder for at brevstemme

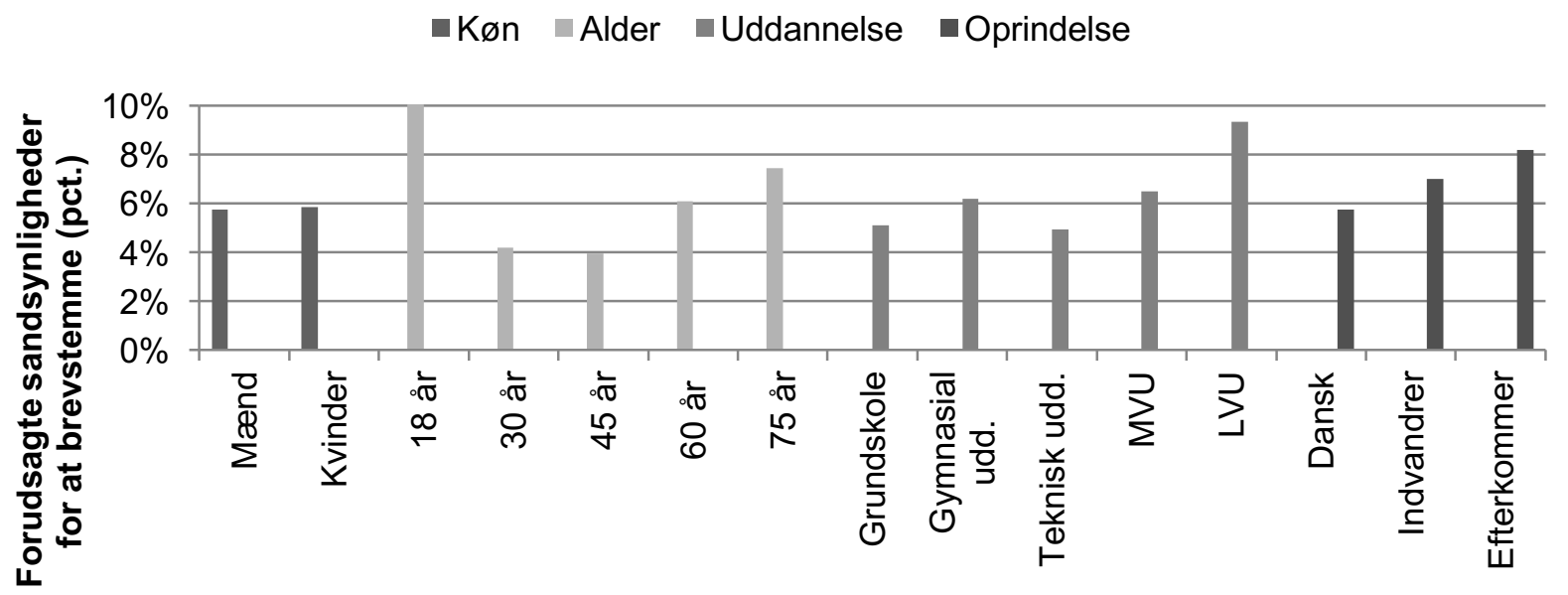

Note: Figuren baserer sig fra forudsagte sandsynligheder fra en logistisk regression med brevstemme som afhængig variabel og køn, alder (årsdummies op til 90 år), uddannelse (5 kategorier), indkomst og oprindelse som uafhængige variable. De forudsagte sandsynligheder er udregnet, hvor de øvrige variable er fastholdt ved deres faktiske værdi.

Ud fra figur 5 kan vi eksempelvis se, at der er næsten dobbelt så stor sandsynlighed for, at en 75årig, der stemmer, vælger at brevstemme sammenlignet med en 30-årig, når køn, uddannelse, indkomst og oprindelse holdes konstante. Ligeledes ser vi, at de teknisk uddannede i mindre grad brev- 
stemmer end andre uddannelsesniveauer. Endeligt står det klart, at borgere med dansk oprindelse også er mindre flittige til at brevstemme end indvandrere og ikke mindst efterkommere - også når der tages højde for de øvrige variable. Mænd og kvinder brevstemmer stort set lige hyppigt. Samlet set fortæller figuren os, at det især er det at være ung og ældre, at have en lang videregående uddannelse samt at være efterkommer, der trækker sandsynligheden for at brevstemme op.

\section{Konklusioner og implikationer}

Som vi har vist i denne artikel, har der været en vis udvikling i brevstemmers status på det lovgivningsmæssige plan, hvor kravet om, at man skal være forhindret $i$ at møde op på valgdagen for at brevstemme nu er fjernet fra lovgivningen, ligesom kommunerne har fået yderligere fleksibilitet $\mathrm{i}$ forhold til placeringen af brevstemmesteder. På det empiriske plan er brevstemmeandelen steget stødt siden 1970. Samtidig står det også klart, at danske vælgere brevstemmer markant mindre end vælgerne i de øvrige nordiske lande, og stigningerne er selv efter de nylige ændringer langt fra et niveau, der kan udfordre dette mønster på kort og mellemlagt sigt. I den forbindelse er det værd at bemærke, at der er andre traditioner forbundet med at brevstemme i de øvrige lande. Således "forhåndsstemmer" man i Norge, og man "förtidsröstar" i Sverige - i begge lande ord, som simpelthen indikerer, at man blot foretager stemmehandlingen inden valgdagen.

Ser man på det kommunale niveau er der betydelig variation i brevstemmeprocenten. Der er ikke nogen klar sammenhæng mellem høj valgdeltagelse og høj brevstemmeprocent, men derimod synes særligt borgere i ø-kommuner, rige kommuner samt kommuner i hovedstadsområdet at gøre hyppigt brug af brevstemmer. For ø-kommunernes vedkommende kan det skyldes, at mange arbejder væk fra øerne, mens der for de rige kommuners vedkommende kan være stor rejseaktivitet.

Når vi fokuserer på individniveau og anvender et detaljeret datasæt for over to millioner vælgere fra Kommunalvalget i 2013 viser analysen, at det især er de ældste borgere, som benytter sig af brevstemmerne. Det er ikke overraskende, idet et svigtende helbred med alderen kan gøre turen til valgstedet vanskeligere samtidig med, at der i mange kommuner laves tiltag for at hjælpe de ældre borgere ved eksempelvis at lade dem brevstemme på plejehjem eller ved at afhente deres brevstemmer. I den modsatte ende af aldersspektret så vi til gengæld noget mere opsigtsvækkende. Således var de yngste vælgere en del mere flittige brevstemmere end andre vælgere. Faktisk er de yngste vælgere ligeså hyppige brevstemmere som pensionister. En mulig forklaring på dette kan være, at en række kommuner gjorde en særlig indsats ved kommunalvalget for at få de unge til at stemme. Et hyppigt anvendt initiativ var at opstille brevstemmesteder på ungdomsuddannelserne, 
og på en del uddannelser blev der afsat undervisningstid til at brevstemme. Analyserne viser da også, at de 18-19 årige, der er under uddannelse, brevstemte betydeligt mere end den tilsvarende aldersgruppe uden for uddannelsessystemet. Der kan således være fordele forbundet med at udbrede brugen af alternative stemmesteder, hvis det, ved eksempelvis at øge opmærksomheden om valget, kan være med til at øge den samlede valgdeltagelse. Hvorvidt dette faktisk er tilfældet, kan vi dog ikke sige på nuværende tidspunkt.

På længere sigt er det værd at interesse sig for, hvordan de unge, der fik mulighed for at stemme på deres uddannelsesinstitution ved deres første valg, forholder sig ved de kommende valg. Således kan én bekymring være, at man gør de unge forvente. Når der så ikke er et valgsted foran deres næse ved næste valg, risikerer man, at de vælger sofaen i stedet for valglokalet. På den måde er der en risiko for, at den kortsigtede strategi med at gøre det lettere at stemme for de unge vil have en boomerangeffekt på længere sigt. En anden mulighed er, at de fortsætter med at brevstemme til de kommende valg og dermed får indlejret andre traditioner for stemmeafgivningen. Endeligt kan det være, at de simpelthen får etableret valgdeltagelsesvanen og stemmer uanset, hvor ubekvemt det måtte være ved de kommende valg. Hvis det er tilfældet, vil deltagelsen på både kort og langt sigt øges for dem, der har fået lettere adgang til brevstemmesteder.

Den øgede brug af brevstemmer ved danske valg samt de seneste års tiltag for at gøre det lettere at brevstemme er værd at holde øje med ved de kommende valg. Således kan en mere udbredt brevstemmebrug have væsentlige perspektiver for administrationen af valg, for aktørerne i valgkampene og for vælgerne.

For det første kan de administrative aspekter fremhæves. Imens valgstederne på valgdagen i høj grad bemandes af frivillige, er det kommunalt ansatte, der varetager brevstemmerne. Samtidig skal det hele foregå på en ordentlig måde, hvilket kræver gode administrative procedurer. En overslagsberegning fra Århus Kommune fra Kommunalvalget i 2009 viste, at en almindelig stemme koster ca. 50 kroner at administrere, imens en brevstemme koster ca. 100 kroner. Hvis vi antager, at ca. tre millioner stemmer til et valg, er prisen således 1,5 millioner kroner pr. procentpoint vælgere, der skifter til brevstemmer frem for almindelige stemmer (Bhatti et al., 2013). Sådanne beregninger er naturligvis behæftet med visse usikkerheder, men ikke desto mindre er det værd at tage med, da det p.t. er de bedste estimater, vi har. Derudover kan det have konsekvenser for planlægningen af valg, når kommunalt ansatte skal klædes på til at tage imod flere brevstemmer. Det kræver ordentlig forberedelse at lave sådan et skift. 
For det andet er det værd at tænke over, at valgkampens natur kan ændre sig. Hvis flere og flere vælgere stemmer inden valgdagen, kan det være, at partierne vil begynde at føre valgkamp tidligere eller lægge en større del af indsatsen tidligt i valgkampen. For medierne og de andre aktører, der er interesserede i valget, kan dette også have betydning for, hvordan de skal forholde sig i tiden op til et valg. Om det er godt eller skidt, hvis valgkampenes natur og timing ændres, er der ikke noget entydigt svar på. Og vi er heller ikke i en situation, hvor det for alvor er tilfældet. Men i kommuner med en relativ høj brevstemmeprocent og et tæt valgresultat, kan det være væsentlig at overveje, om valgkampen blev ført og dækket ordentlig i den periode, hvor brevstemmerne besluttede sig.

Det leder os videre til det tredje perspektiv, nemlig vælgerne. Hvis vælgere får en vane med at brevstemme eller det i stigende grad forventes af dem, vil det stille nye krav til dem. Som brevstemmere må de søge den nødvendige information tidligere, og sager, der opstår $\mathrm{i}$ de sidste dage $\mathrm{i}$ valgkampen, vil ikke komme i betragtning. Vælgerne kan trods alt stadig gå ned og stemme på ny og dermed annullere den gamle stemme, men det er for det første en stor indsats og for det andet kan det være, at deres politiske opmærksomhed daler, når de har afgivet deres stemme. Præcis hvad mekanismerne vil være, er svært at sige, men situationen som vælger kan ændre sig som konsekvens af den øgede brug af brevstemmer.

Samlet set har denne artikel bidraget med ny viden om brevstemmer i Danmark samt i sammenligning med nordiske lande og USA. Det er vores håb, at vi ved at tilvejebringe denne viden kan hjælpe med en mere oplyst debat om brugen af brevstemmer. Formålet med dette studie er deskriptivt. Det næste skridt for fremtidige studier kunne være det mere kausale spørgsmål omkring, hvorvidt der er en kausal effekt af at gøre det lettere at brevstemme på den samlede valgdeltagelse. Forhåbentlig vil fremtidige undersøgelser gøre os klogere på dette spørgsmål.

\section{Litteratur}

Aldrich, John H 1993. Rational choice and turnout. American Journal of Political Science: 246-278.

Bhatti, Yosef, Dahlgaard, Jens Olav, Hansen, Jonas Hedegaard \& Hansen, Kasper Møller 2014a. Kan man øge valgdeltagelsen? Analyse af mobiliseringstiltag ved kommunalvalget den 19. november 2013 København: Institut for Statskundskab, Københavns Universitet.

Bhatti, Yosef, Dahlgaard, Jens Olav, Hansen, Jonas Hedegaard \& Hansen, Kasper Møller 2014b. Hvem stemte til EP-valget 2014? Valgdeltagelsen ved Europa-Parlamentsvalget 25. maj 2014. 
Beskrivende analyser af valgdeltagelsen baseret på registerdata, København: Institut for Statskundskab, Københavns Universitet.

Bhatti, Yosef, Dahlgaard, Jens Olav, Hansen, Jonas Hedegaard \& Hansen, Kasper Møller 2014c. Hvem stemte og hvem blev hjemme? Valgdeltagelsen ved kommunalvalget 19. november 2013. Beskrivende analyser af valgdeltagelsen baseret på registerdata, København: Institut for Statskundskab, Københavns Universitet.

Bhatti, Yosef, Dahlgaard, Jens Olav, Hansen, Jonas Hedegaard, Hansen, Kasper Møller \& Olsen, Mariann Malchau. 2013. Kommunalvalgets stemmekrise: Ingen garanti for at flere brevstemmer er løsningen. Available: http://raeson.dk/2013/kommunalvalgets-stemmekrise-ingen-garanti-forat-flere-brevstemmer-er-losningen/.

Bhatti, Yosef \& Hansen, Kasper Møller 2010. Valgdeltagelsen ved kommunalvalget 17. november 2009. Beskrivende analyser af valgdeltagelsen baseret på registerdata. Arbejdspapir Københavns Universitet, Institut for Statskundskab, 2010(3).

Blais, André, Dobrzynska, Agnieszka \& Loewen, Peter 2007. Potential Impacts of Extended Advance Voting on Voter Turnout: Elections Canada.

Blais, André, Young, Robert \& Lapp, Miriam 2000. The calculus of voting: An empirical test. European Journal of Political Research, 37(2): 181-201.

Brady, Henry \& McNulty, John 2011. Turning out to vote: The costs of finding and getting to the polling place. American Political Science Review, 105(1): 115-134.

Dahlberg, Stefan, Oscarsson, Henrik \& Öhrvall, Richard 2007. Förtidsröstning. Förtidsröstningsreformens effekter på individers röstningsbenägenhet vid de allmänna valen 2006. Göteborgs Universitet. Göteborg / Stockholm: Göteborgs Universitet.

Danmarks Statistik 2010. Valgene til kommunalbestyrelser og regionsråd 17. november 2009. Befolkning og valg 2010:4, København Ø: Danmarks Statistik.

Danmarks Statistik 2014. Valgene til kommunalbestyrelser og regionsråd 19. november 2013. Befolkning og valg 2014:2, København Ø: Danmarks Statistik.

Danmarks Statistik 2015. Folketingsvalget den 18. juni 2015. Befolkning og valg 2015:3, København Ø: Danmarks Statistik.

Downs, Anthony 1957. An Economic Theory of Democracy, New York: Harper and Row.

Elklit, Jørgen, Møller, Birgit, Svensson, Palle \& Togeby, Lise 2005. Gensyn med sofavaelgerne. Valgdeltagelse i Danmark, Århus: Århus Universitetsforlag. 
Elklit, Jørgen \& Togeby, Lise 2009. Where turnout holds firm: the Scandinavian exceptions. s. 83105 I: Debardeleben, Joan \& Pammett, Jon H (red.) Activating the Citizen: Dilemmas of Citizen Participation in Europe and Canada.

Franklin, Mark N 1999. Electoral engineering and cross-national turnout differences: what role for compulsory voting? British Journal of Political Science, 29(01): 205-216.

Franklin, Mark N. 2004. Voter turnout and the dynamics of electoral competition in established democracies since 1945, Cambridge.

Gronke, Paul, Galanes-Rosenbaum, Eva, Miller, Peter A \& Toffey, Daniel 2008. Convenience voting. Annu. Rev. Polit. Sci., 11: 437-455.

Kommission Om Livskvalitet Og Selvbestemmelse I Plejebolig Og Plejehjem 2012. Livskvalitet og selvbestemmelse på plejehjem. I: Ældrekommissionen (ed.). Social- og Integrationsministeriet.

Ladner, Andreas \& Pianzola, Joëlle 2010. Do Voting Advice Applications Have an Effect on Electoral Participation and Voter Turnout? Evidence from the 2007 Swiss Federal Elections. s. 211-224 I: Tambouris, Efthimios, Macintosh, Ann \& Glassey, Olivier (red.) Electronic Participation. Springer Berlin Heidelberg.

Lassen, David Dreyer 2005. The effect of information on voter turnout: Evidence from a natural experiment. American Journal of Political Science, 49(1): 103-118.

Ministry of Justice Finland. 2012. Participation [Online]. Ministry of Justice Finland, http://tulospalvelu.vaalit.fi/K2012/e/aanaktiivisuus/aanestys1.htm (24-11 2015).

Ministry of Justice Finland. 2015. Voter turnout [Online]. Ministry of Justice Finland, http://tulospalvelu.vaalit.fi/E-2015/en/aanestys1.html (24-11 2015).

Neeley, Grant W \& Richardson, Lilliard E 2001. Who is early voting? An individual level examination. The Social Science Journal, 38(3): 381-392.

Oscarsson, Henrik \& Holmberg, Sören 2013. Nya Svenska Väljare, Stockholm: Norstedts Jurdik.

Riker, William H. \& Ordeshook, Peter C. 1968. A Theory of the Calculus of Voting. American Political Science Review, 62(01): 25-42.

Statistics Iceland. 2015a. Local government elections [Online]. Statistics Iceland, http://old.statice.is/Statistics/Elections/Local-goverment-elections (24-11 2015).

Statistics Iceland. 2015b. General elections [Online]. Statistics Iceland, http://old.statice.is/Statistics/Elections/General-elections (24-11 2015).

Statistics Norway. 2013. Stortingsvalet, 9. september 2013 [Online]. Statistics Norway, http://www.ssb.no/valg/statistikker/stortingsvalg (24-11 2015). 
Statistics Norway. 2015. Kommunestyre- og fylkestingsvalget, 2015 [Online]. Statistics Norway, http://www.ssb.no/valg/statistikker/kommvalg (24-11 2015).

U.S. Election Assistance Commission 2013. The 2012 Election Administration and Voting Survey. U.S. Election Assistance Commission.

Valgloven 2015. Valgloven.

Wolfinger, Raymond E \& Rosenstone, Steven J 1980. Who Votes?, New Haven, CT: Yale University Press.

\section{Appendiks}

Figur A.1: Brevstemmeprocent og valgdeltagelse på kommuneniveau i 2009

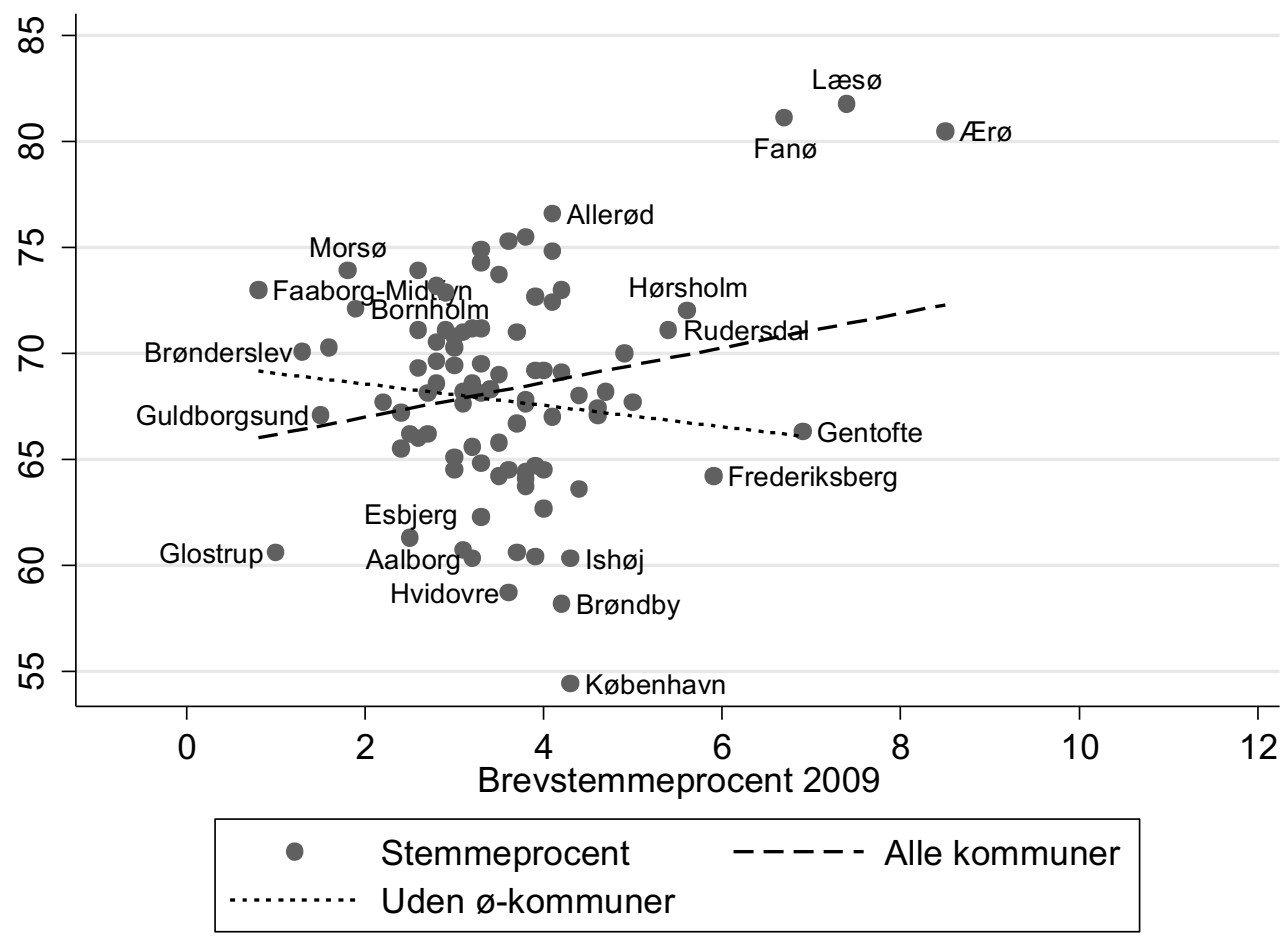

Note: Der mangler brevstemmeprocenter for seks kommuner i 2009 (Lejre, Samsø, Syddjurs, Vejen, Ikast-Brande og Mariagerfjord). Data fra (Danmarks Statistik, 2010). 
Figur A.2: Førstegangsvælgeres brevstemmeprocent i 2013 opdelt på igangværende uddannelse

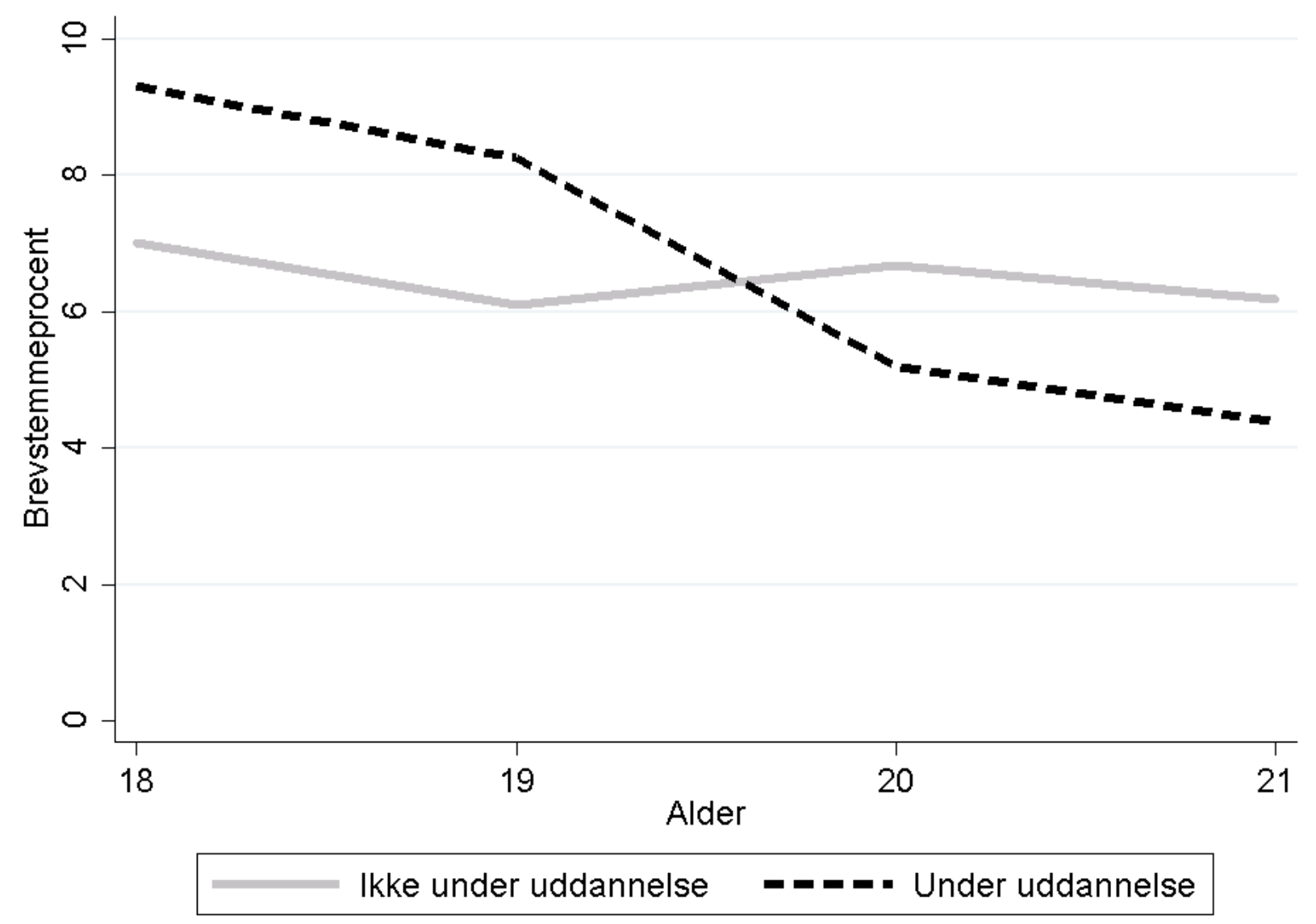

